\title{
CYTOPLASMIC OESTRADIOL-BINDING SITES AND THEIR RELATIONSHIP TO OESTRADIOL CONTENT IN THE ENDOMETRIUM OF CATTLE
}

\author{
B. E. SENIOR \\ National Institute for Research in Dairying, \\ Shinfield, Reading RG2 9AT
}

(Received 21st November 1974)

\begin{abstract}
Summary. Twenty-three cows and heifers were killed at known times during the oestrous cycle or during the first 35 days of pregnancy. Duplicate cytosol preparations were made from the endometrium of each uterine horn and both the binding-site concentration and the oestradiol level were determined for each sample. During the cycle, the oestradiol concentration was only 0.2 to $1.7 \%$ of the concentration of binding sites which varied considerably between Days 19 and 5 $(47,665 \pm 7538$ sites/cell, mean \pm S.E.M.) and Days 6 to $18(7060 \pm 444$ sites/cell). The concentration of binding sites remained low in pregnant animals $(6689 \pm 492)$, although the oestradiol concentration was high about 20 days after insemination, resulting in almost $14 \%$ of the sites being occupied. Five inseminated animals in which no conceptus was found when they were slaughtered 19 to 22 days later had low concentrations of binding sites but two animals had high levels of oestradiol with $13 \%$ and $15 \%$, respectively, of their cytoplasmic sites being occupied. It is suggested that these animals had recently lost their conceptuses. Two ovariectomized cows and one non-cyclic animal contained high concentrations of oestradiol-binding sites in the uterine cytoplasm. No significant difference was found between the uterine horn adjacent to the ovary with the CL and the contralateral horn in early pregnancy or during the luteal phase of the oestrous cycle. An animal killed 1 week after parturition contained fourfold more sites in the involuting horn than in the opposite horn. It is suggested that progesterone plays a major role in regulating oestrogen-induced replacement of cytoplasmic binding sites.
\end{abstract}

\section{INTRODUCTION}

A relatively high proportion of cattle return to oestrus within 25 days after insemination due to embryonic mortality during this period (Hawk et al., 1955) and the importance of the uterine environment for successful pregnancy has been emphasized by the egg-transfer experiments of Rowson et al. (1972). In many species, the role of the ovarian steroid hormones in maintaining the function of the uterus and in controlling the implantation of the conceptus has 
been recognized (Hawk et al., 1963; Martin et al., 1970; Nalbandov, 1971; Lee \& Dukelow, 1972; Katzenellenbogen \& Gorski, 1972; Finn \& Martin, 1973; Gentry et al., 1973; Brinsfield \& Hawk, 1974).

The nature of the uptake of oestrogens by the uterus has been demonstrated by Jensen \& Jacobson (1962) and Jensen \& De Sombre (1972) and, for the bovine uterus, a cytoplasmic oestradiol-binding protein, responsible for the transfer of oestradiol into the cell nucleus to initiate its action, has been described by Puca et al. (1971), De Sombre et al. (1971), Wagner et al. (1972) and Jackson \& Chalkley (1974a). The aim of this investigation was to measure the concentration of the cytoplasmic binding protein during the oestrous cycle and in early pregnancy and to relate this to the concentration of oestradiol in the cytoplasm at the same time.

The bovine blastocyst develops initially in one uterine horn and must influence the uterus during early pregnancy to abolish the luteolytic action (Dobrowolski \& Hafez, 1971), possibly by modifying the uptake of steroids. Samples from the two uterine horns were therefore analysed separately for each animal.

\section{MATERIALS AND METHODS}

\section{Experimental animals}

The 27 animals used in this investigation were either cows culled from herds at the Institute for Research on Animal Diseases, Compton, Berks (I.R.A.D.), or cows and heifers of various breeds purchased by the National Institute for Research in Dairying, Shinfield, Reading, Berks (N.I.R.D.), and the Ministry of Agriculture, Fisheries and Food Cattle Breeding Centre, Shinfield, Reading, Berks (M.A.F.F.), for this or related investigations. These animals included two that were ovariectomized and a cow that was 1 week post partum. All the others, except one (Table 1), displayed normal oestrous cycles. The timing of the oestrous cycles was inferred from observation of oestrous behaviour, confirmed, when possible, by the use of 'Kamar' mount detectors (Kamar Inc., Steamboat Springs, Colorado, U.S.A.) and determination of peripheral plasma progesterone concentrations (Glencross et al., 1973).

Animals were killed at I.R.A.D. at known times after oestrus or insemination. The reproductive tract was removed within 2 to $3 \mathrm{~min}$ of slaughter and gross ovarian morphology was noted. After removal of the mesometrium, the left and right uterine horns were separated and, if the cow had been inseminated, $0.9 \%$ sodium chloride solution was flushed from the uterotubal junction through each horn. Animals were considered pregnant only if a conceptus was recovered. The uterine horns were returned on ice to the laboratory (N.I.R.D.) where they were cut open longitudinally and the endometrium was teased away from the myometrium.

Nine cows were killed at known times during the oestrous cycle and fourteen cows were killed at various intervals after having been inseminated on the day of oestrus. A blastocyst was recovered from seven of the fourteen cows; the others were taken to be a separate group which failed to conceive or to maintain their conceptuses. 
Preparation of cytosol

Freshly obtained endometrium (approximately $1 \mathrm{~g}$ ) was weighed and homogenized at $4^{\circ} \mathrm{C}$ in $10 \mathrm{ml}$ of $0.01 \mathrm{M}$-tris-HCl buffer, $\mathrm{pH} 8$ (containing 0.001 M-EDTA and $0.25 \mathrm{M}$-sucrose) using $3 \times 5 \mathrm{sec}$ pulses of a Silverson homogenizer (Silverson Machines Ltd, Chesham, Bucks) and cooling for 1 min between pulses. The homogenate was centrifuged at $105,000 \mathrm{~g}$ and the supernatant (cytosol) was decanted from the nuclear pellet. The pellet was washed with $2 \mathrm{ml}$ buffer and the combined volume of cytosol was noted. Part of this cytosol preparation $(2.4 \mathrm{ml})$ was used immediately to assay the concentration of oestradiolbinding sites and the remainder was stored at $-20^{\circ} \mathrm{C}$ and assayed for oestradiol concentration at a later date.

The content of DNA in the nuclear pellet was determined according to the method of Burton (1956).

\section{Assay of the concentration of cytoplasmic oestradiol-binding sites}

The assay was a modification of that of Mester et al. (1970). Each cytosol preparation was incubated in $200-\mu$ l aliquots with $0,50,100,200,400$ and 800 pg (each in duplicate) oestradiol- $17 \beta$ together with $20 \mathrm{pg}(16,000 \mathrm{~d} / \mathrm{min})$ of $\left[2,4,6,7-{ }^{3} \mathrm{H}\right]$ oestradiol- $17 \beta$. The incubation was carried out at $4^{\circ} \mathrm{G}$ for $17 \mathrm{hr}$. Bound and free oestradiol were separated by incubating the mixture with 500 $\mu \mathrm{l}$ dextran-coated charcoal suspension $(0.25 \%$ Norit A charcoal and $0.025 \%$ dextran, mol. wt 20,000 in tris- $\mathrm{HCl}$ buffer) for $20 \mathrm{~min}$ at $4^{\circ} \mathrm{C}$. The 20 -min exposure to charcoal gave time for dissociation of oestradiol from non-specific low-affinity sites to occur. Dissociation of oestradiol from specific receptors may also occur to a limited extent but, since the exposure time to charcoal was carefully controlled, the effect was standardized. The number of specific binding sites in the cytosol preparation was then determined by Scatchard (1949) plot analysis. From the DNA content of the nuclear pellet and an assumed mean value of $6 \mathrm{pg}$ DNA/cell (Mahler \& Cordes, 1966), the numbers of oestradiolbinding sites/cell were calculated.

For each animal, the endometrium from the left and right uterine horn was assayed separately. The concentration of binding sites in each horn was determined in duplicate.

Since this assay determines only the number of sites not already occupied by oestradiol, the total number of sites/cell was calculated when required by adding the number of molecules of oestradiol/cell, i.e. the number of occupied sites/ cell, to the number of free sites.

\section{Assay of cytoplasmic oestradiol concentration}

A known amount $(12 \mathrm{pg}, 10,000 \mathrm{~d} / \mathrm{min})$ of $\left[2,4,6,7-{ }^{3} \mathrm{H}\right]$ oestradiol- $17 \beta$ was added to the cytosol sample which was then extracted with three $20-\mathrm{ml}$ vols of diethyl ether. The combined ether extract was chromatographed on a column of Sephadex LH-20 using the solvent system $85 \%$ toluene : $15 \%$ methanol (Glencross et al., 1973) to obtain a fraction containing oestradiol. This fraction was made up in $1 \mathrm{ml}$ redistilled toluene; a $100-\mu \mathrm{l}$ aliquot was removed to estimate the procedural loss of radioactivity and two $100-\mu \mathrm{l}$ and two $300-\mu \mathrm{l}$ aliquots were used for radioimmunoassay (Glencross et al., 1973). The oestradiol content 
of the whole cytosol sample was calculated from the difference between the mean quantity determined with the 100- $\mu$ l aliquots and the mean for the $300-\mu 1$ aliquots. This method of calculation gave values very similar to those obtained when calculations were made from each of the four determinations separately. This similarity implies that the regression lines of oestradiol assayed against the volume of extract used for the assay pass close to the origin. Hence, the doseresponse line for the extract is parallel to that of the oestradiol standard.

The oestradiol results were expressed as $\mathrm{pg} / \mathrm{g}$ (wet weight) of whole endometrium and, using the DNA content of the nuclear pellet, as number of molecules per cell. If it is assumed that these molecules are all bound to the cytoplasmic sites, then this gives an estimate of the number of oestradiol-binding sites that are occupied. The proportion of sites which are occupied can thus be ascertained.

\section{Oestradiol-binding sites}

\section{RESULTS}

The Scatchard plot showing the binding protein assay for the duplicated samples from the left and right horn from one cow is reproduced in Text-fig. 1. All of the Scatchard plots demonstrated the presence of high affinity receptors in the cytoplasm. The dissociation constants varied between 0.5 and $2.5 \times 10^{-10}$ $\mathrm{mol} /$ litre. In most cases, a low affinity receptor was demonstrable in the presence

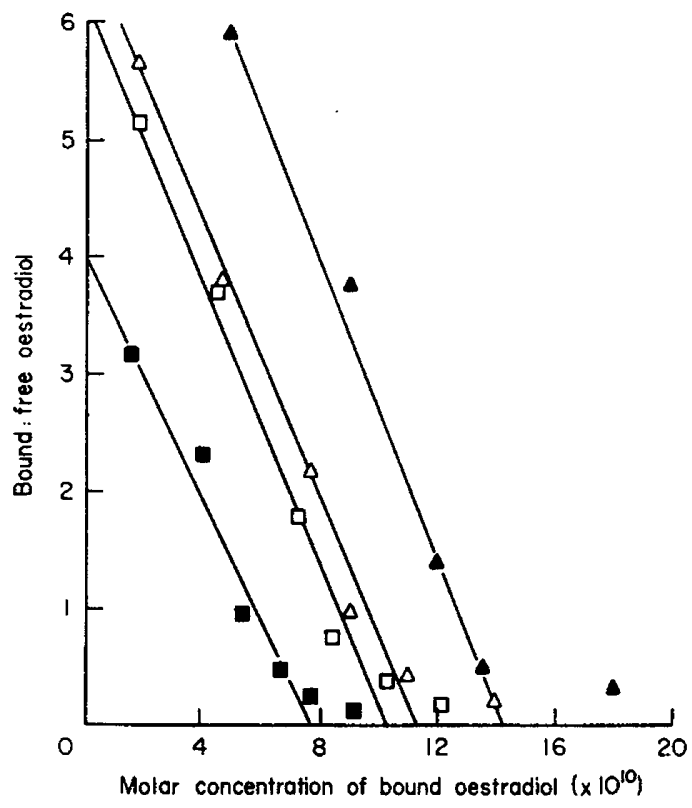

TexT-FIG. 1. Scatchard plot analysis of data obtained by incubating cytosol preparations from bovine endometrium with increasing concentrations of oestradiol-17 $\beta$. Values of binding-site concentration obtained from the intercept of the plot with the ' $x$-axis' were corrected for the volume of cytosol obtained and the DNA content of the nuclear pellet. $\square=$ left uterine horn, Sample 1; $\Delta=$ right uterine horn, Sample 1; $=$ = left horn, Sample 2; $\Delta=$ right horn, Sample 2. Each point is the mean of duplicate determinations. 
of $400 \mathrm{pg}$ and $800 \mathrm{pg}$ of oestradiol. The binding to this receptor was not eliminated by incubation with dextran-coated charcoal at $30^{\circ} \mathrm{C}$ as suggested by Mester et al. (1970).

The mean concentrations of binding sites in animals in various reproductive states are shown in Table 1. During the oestrous cycle, there was a six- to sevenfold increase in mean concentration on Days 19 to 5 compared with Days 6 to 18 (when the GL is most active). This variation is further illustrated in Text-fig. 2. The concentration of sites throughout the first 35 days of pregnancy differed little from that during the luteal phase of the oestrous cycle. One animal that appeared to have inactive ovaries (no CL or macroscopically visible follicles) had a mean concentration of sites within the range found between Days 19 and 5 of the oestrous cycle. Two cows which had been ovariectomized for some months also contained a significantly higher number of sites/cell than animals in the luteal phase of the oestrous cycle. During the oestrous cycle and early pregnancy, there was no significant difference between the left and right uterine horns or between the horn adjacent to the ovary containing the CL and the contralateral horn (see also Text-fig. 2. The only animal in this investigation in which a clear difference was observed between the two uterine horns was that killed 1 week after parturition. The concentration in the horn that had contained the calf was approximately $\times 4$ that in the opposite horn.

Table 1. Concentrations of oestradiol-binding sites in the cytoplasm of endometrium from cows in various reproductive states

\begin{tabular}{lccc}
\hline \multicolumn{1}{c}{ Reproductive state } & $\begin{array}{c}\text { No. of } \\
\text { animals }\end{array}$ & $\begin{array}{c}\text { No. of } \\
\text { samples }\end{array}$ & $\begin{array}{c}\text { No. of binding sites/cell } \\
\text { (Mean } \pm \text { S.E.) }\end{array}$ \\
\hline Oestrous cycle & & & \\
$\quad$ Days 19 to 5 & $4 *$ & 16 & $47,665 \pm 7,538$ \\
$\quad \begin{array}{l}\text { Days 6 to 18 } \\
\text { Pregnancy (up to } 35 \text { days) }\end{array}$ & 7 & 24 & $7,060 \pm 444$ \\
Non-cyclic & 7 & 28 & $6,689 \pm 492$ \\
$\quad$ (inactive ovaries) & 1 & 4 & $32,200 \pm 2,751$ \\
Ovariectomized & 2 & 4 & $21,050 \pm 2,066$ \\
1 week post partum & 1 & 2 & $23,150 \pm 5,500$ \\
$\quad$ Previously gravid horn & 1 & 2 & $5,850 \pm 1,100$ \\
\hline Previously empty horn & 1 & & \\
\hline
\end{tabular}

* Includes Cow E/11 (Table 2).

Relationship between the concentrations of oestradiol-binding sites and endogenous oestradiol in the cytoplasm

Oestrous cycle. The concentration of binding sites, the number of molecules of oestradiol/cell and the percentage of sites occupied during the oestrous cycle are shown for individual cows in Text-fig. 2. The mean concentration of oestradiol for individual animals varied between 4 and $118 \mathrm{pg} / \mathrm{g}$ (wet weight) of endometrium, and the concentration of binding sites between 5629 and 96,710 /cell. The proportion of sites occupied by oestradiol remained low, in the 


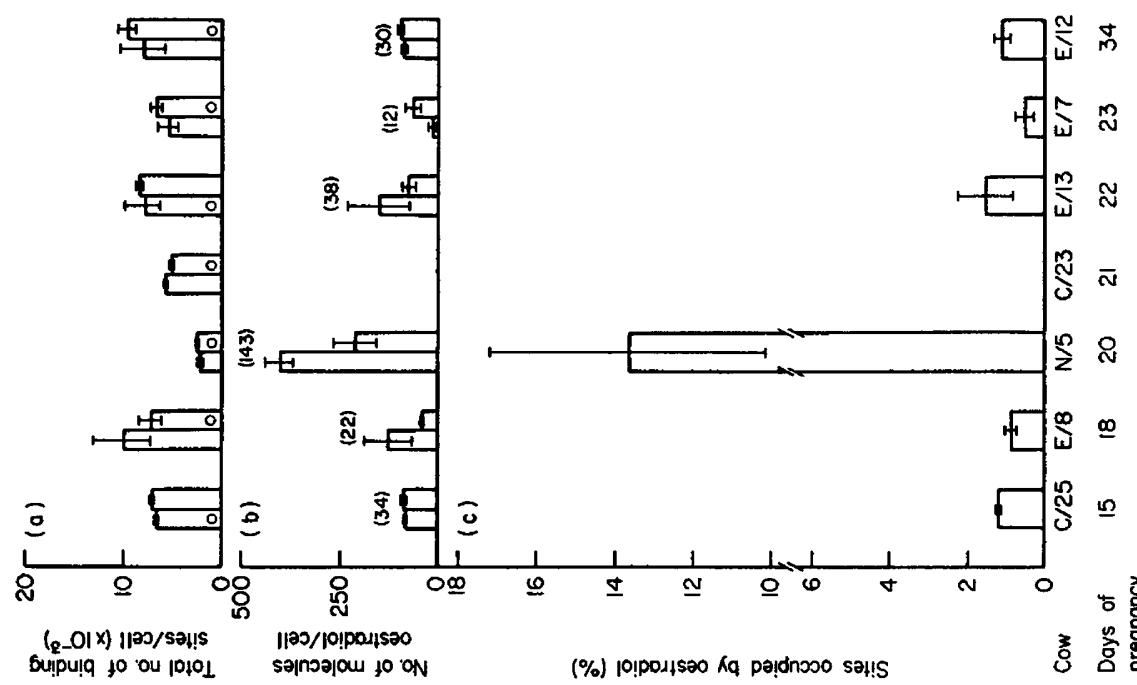

它.

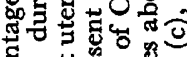

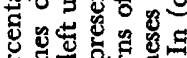

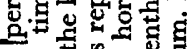

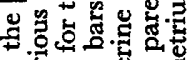
(5) व 한 응. 政

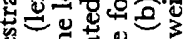
웡 엉형

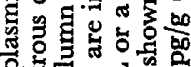

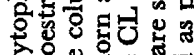

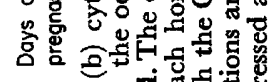
3. 可解

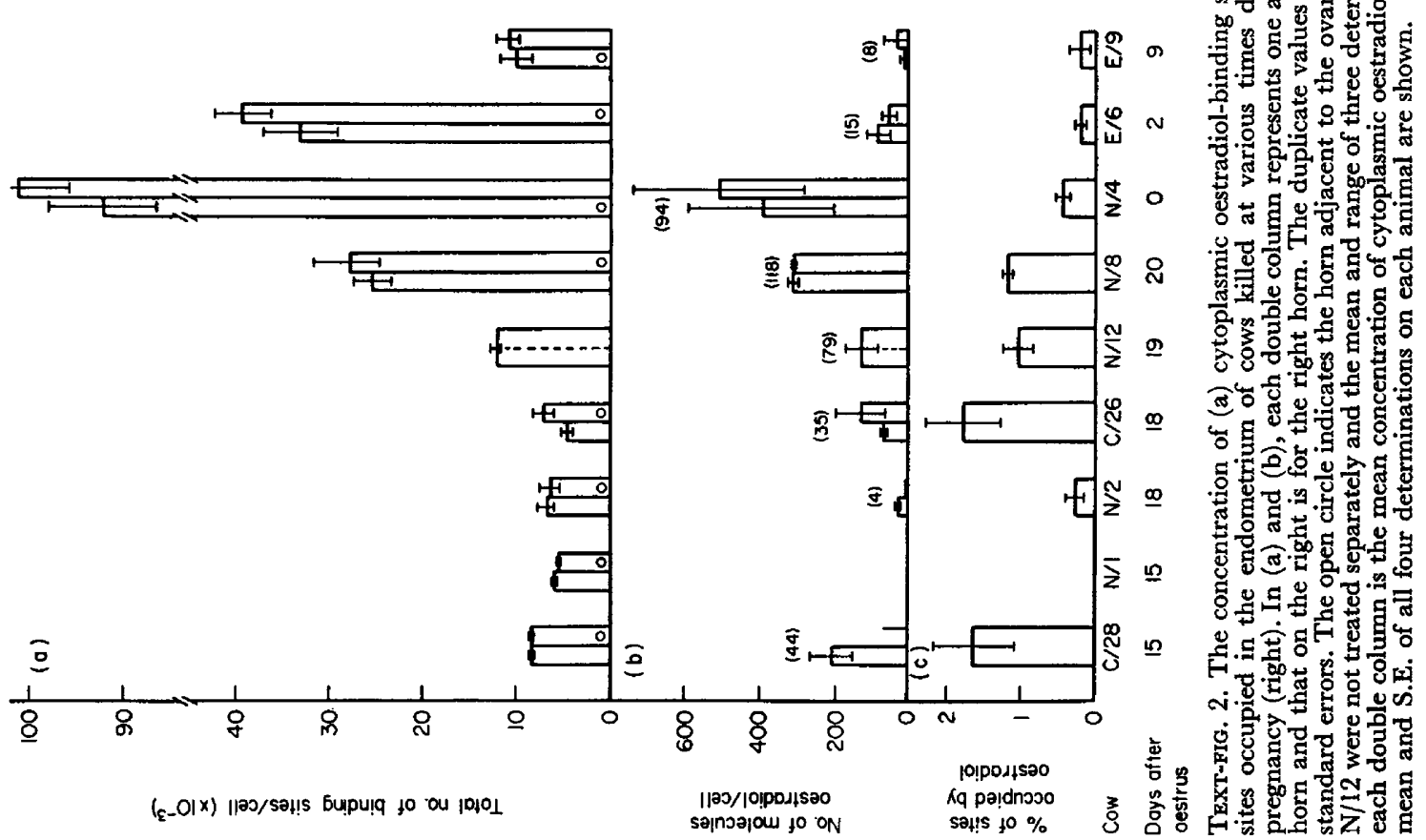


range 0.2 to $1.7 \%$. As the concentration of oestradiol increased progressively in cows killed on Days 18, 19 and 20, so the binding site concentration increased, the proportion of sites occupied remaining almost constant. In one cow killed on the day of oestrus, the number of sites/cell was very large and, although the oestradiol concentration was also high, the proportion of sites occupied was more than halved compared with Days 18 to 20. This low proportion was maintained in two cows killed on Days 2 and 9 after oestrus since the endogenous oestradiol rapidly returned to basal levels while the number of binding sites fell more slowly. A slightly elevated level of oestradiol was also found in one animal killed on Day 15 of the cycle.

Pregnancy. Throughout all the stages of pregnancy investigated, the binding site concentration remained below $10,000 /$ cell although the oestradiol concentration varied from 12 to $143 \mathrm{pg} / \mathrm{g}$ wet weight (Text-fig. 2). In one animal killed on Day 20, the mean proportion of sites occupied ( \pm S.E.M.) reached $13 \cdot 65 \pm 3 \cdot 51 \%$ (four samples).

Table 2. Concentrations of oestradiol and of oestradiol-binding sites in the cytoplasm of endometrium from cows which were inseminated but in which no conceptus was found

\begin{tabular}{|c|c|c|c|c|c|c|}
\hline $\begin{array}{l}\text { Cow } \\
\text { No. }\end{array}$ & $\begin{array}{l}\text { Days after } \\
\text { insemination }\end{array}$ & $\begin{array}{l}\text { No. of binding sites/cell } \\
(\text { Mean } \pm S . E . M .)\end{array}$ & $\begin{array}{l}\text { Oestradi } \\
(p g / g)\end{array}$ & $\begin{array}{l}\text { iol concentration } \\
(\text { molecules/cell })\end{array}$ & $\begin{array}{l}\% \text { Sites } \\
\text { occupied }\end{array}$ & $\begin{array}{c}\text { Data } \\
\text { similar } \\
\text { to that* } \\
\text { for: }\end{array}$ \\
\hline $\begin{array}{l}N / 7 \\
C / 27 \\
C / 24 \\
\text { E/10 } \\
\text { N/9 } \\
\text { N/6 } \\
\text { E/11 }\end{array}$ & $\begin{array}{l}14 \\
19 \\
20 \\
21 \\
22 \\
22 \\
25\end{array}$ & $\begin{array}{c}5,367 \pm 179 \\
7,575 \pm 1,068 \\
6,249 \pm 770 \\
9,685 \pm 1,124 \\
7,476 \pm 246 \\
8,826 \pm 1,099 \\
30,407 \pm 1,199\end{array}$ & $\begin{array}{c}141 \pm 23 \\
57 \pm 25 \\
325 \pm 63 \\
13 \pm 6 \\
160 \pm 13 \\
539 \pm 66 \\
193 \pm 17\end{array}$ & $\begin{array}{c}390 \pm 64 \\
222 \pm 80 \\
811 \pm 176 \\
57 \pm 23 \\
250 \pm 35 \\
1,335 \pm 232 \\
1,392 \pm 183\end{array}$ & $\begin{array}{r}7.29 \pm 1.22 \\
3.61 \pm 1.81 \\
12.94 \pm 2.08 \\
0.64 \pm 0.28 \\
3.36 \pm 0.53 \\
15.03 \pm 1.63 \\
4.64 \pm 0.72\end{array}$ & $\begin{array}{c}\mathbf{L} \text { or } \mathbf{P} \\
\mathbf{P} \\
\mathrm{P} \\
\mathrm{P} \\
\mathbf{P} \\
\mathbf{P} \\
04\end{array}$ \\
\hline
\end{tabular}

The mean and standard error of quadruplicate estimates on each animal are shown.

$* L=$ luteal phase of the oestrous cycle; $P=$ pregnancy; $04=4$ days after oestrus.

Animals inseminated but not found to be pregnant. The results from inseminated animals in which no conceptus was recovered are shown in Table 2. Those animals killed between 19 and 22 days after insemination had similar concentrations of binding sites to those of pregnant animals (Text-fig. 2). The ovaries of Cows C/27 and E/10 contained large GL and those of Cows N/9 and $\mathrm{N} / 6$ contained small $\mathrm{CL}$ which were probably regressing. A recent ovulation point was also present in one ovary of Cow N/6. The ovaries of Cow C/24 contained no CL. An unfertilized ovum together with membranous material which was probably a degenerating blastocyst was flushed from the uterus of Cow E/10 whose right ovary contained a large GL. The concentration of oestradiol in these animals varied between $13 \mathrm{pg} / \mathrm{g}$ and $539 \mathrm{pg} / \mathrm{g}$ and the percentage of sites occupied by oestradiol reached $12.94 \pm 2.08$ and $15.03 \pm 1.63$ in Cows $\mathrm{C} / 24$ and $\mathrm{N} / 6$, respectively.

Cow $\mathrm{N} / 7$, killed 14 days after insemination, could not be distinguished by its binding-site concentration from pregnant cows or those in the luteal phase. The 
oestradiol concentration was, however, elevated and $7 \cdot 29 \%$ of the sites were occupied.

Cow E/11 was characteristic of animals between Days 19 and 5 of the oestrous cycle. Both the oestradiol level and the binding-site concentration were elevated, although the proportion of occupied sites was higher than that of cows during the oestrous cycle. A recent ovulation point was observed in the right ovary and it is probable that the animal was approximately 4 days after oestrus.

\section{DISCUSSION}

Despite difficulty in obtaining a precise determination of the day of slaughter within the oestrous cycle, since the time from the next expected oestrus could only be assumed, the variation in the concentration of oestradiol and its binding sites in endometrial cells towards oestrus bore a striking resemblance to that of the plasma oestradiol concentration (Glencross et al., 1973; Echternkamp \& Hansel, 1973; Dobson \& Dean, 1974). The concentration of oestradiol-binding sites rose sharply over the last 2 to 3 days before oestrus but whereas plasma oestradiol levels declined rapidly during oestrus (R. G. Glencross, personal communication), the binding site concentration remained high for a further 2 days or, if Cow E/11 (Table 2) is included, for 4 days after oestrus. These high levels of binding sites coincide with the period when the concentration of progesterone in the peripheral plasma is low ( $<1 \mathrm{ng} / \mathrm{ml}$, Glencross et al., 1973). Changes in the cytoplasmic concentration of oestradiol-binding sites were also found by Kimball \& Hansel (1973) throughout the bovine oestrous cycle; the levels increased from Day 15 of the cycle onwards and were low on Days 2, 5 and 10. Jackson \& Chalkley (1974b), on the other hand, found no variation in the concentration of cytoplasmic binding sites/cell throughout the bovine oestrous cycle but they did find peaks of nuclear receptor-site level at oestrus and between Days 15 and 19. The reason for these discrepancies is obscure. In women (Evans et al., 1974) and rats (Feherty et al., 1970; Lee \& Jacobson, 1971), changes in the concentration of cytoplasmic oestradiol-binding protein have been found during the reproductive cycle.

The synthesis of oestrogen-binding proteins is influenced by oestrogens themselves; in the rat, the uterine binding-protein levels are elevated approximately $24 \mathrm{hr}$ after oestrogen administration following an initial depletion (Sarff \& Gorski, 1971). The rising concentration of oestradiol in the peripheral plasma shortly before oestrus, which is reflected in the uterine cytoplasm levels, may be the physiological cause of the increased concentration of binding protein. Indeed the binding-protein concentration did appear to rise approximately 1 day later than plasma oestradiol concentration does (R. G. Glencross, unpublished observations). The concentration of oestradiol/g of endometrium was between $\times 10$ and $\times 20$ that $/ \mathrm{ml}$ peripheral plasma (Glencross et al., 1973; Dobson \& Dean, 1974). The nature of the uptake by the uterus cannot, however, be fully understood from such estimates since the oestradiol concentration in the cytoplasm is dependent not only on blood levels but also on the rate of transfer of oestradiol into the cell nucleus. 
The relationship observed around oestrus between uterine oestradiol levels and binding sites differed in pregnancy (Text-fig. 2) and for most of the inseminated animals from which no conceptus was recovered (Table 2). Five animals $(\mathrm{N} / 5, \mathrm{~N} / 6, \mathrm{~N} / 7, \mathrm{~N} / 9$ and $\mathrm{C} / 24)$ had high levels of oestradiol in the cytoplasm but low concentrations of binding sites and, hence, a substantial proportion of the cytoplasmic binding sites were occupied. It appears, therefore, that the peaks of plasma oestradiol during the oestrous cycle and in early pregnancy (Glencross et al., 1973) are reflected in increased concentrations in the cytoplasm of the uterine endometrium but that in the presence of high plasma progesterone levels, the uterine oestradiol does not stimulate changes in its binding-protein concentration. Progesterone may either reduce the uptake of oestradiol by the cell nucleus or it may affect the later stages of binding-protein synthesis once oestradiol has entered the nucleus. Progesterone reduces the oestrogen-induced mitotic rate of mouse uterine epithelial cells (Martin \& Finn, 1970; Martin et al., 1973; Lee, 1974) and the uptake of oestrogens, as shown by autoradiography, into epithelial cell nuclei in this species (Smith et al., 1970; Stumpf \& Sar, 1973). In all of these studies, however, progesterone acted synergistically with oestrogen on uterine stromal cells. Progesterone also enhances the binding capacity of rabbit uterine chromatin for oestradiol (Chatkoff \& Julian, 1973). The effects of progesterone on the concentration of uterine cytoplasmic oestradiol-binding protein in rats depends on the dose and the time after injection (Black \& Kraay, 1973); only one regimen (100 $\mu \mathrm{g}$ injected $1 \mathrm{hr}$ before death) caused a reduction in the concentration of binding protein.

The binding-site concentration in $5 / 7$ cows which were inseminated but not confirmed pregnant was similar to that in pregnant animals. It seems improbable that insemination itself could have been the cause of this difference and it is suggested that these animals conceived and that their conceptuses were lost some days before slaughter leaving insufficient time for the establishment of the binding-site concentrations characteristic of oestrus. Evidence of a degenerating blastocyst was found in Cow E/10.

There was no significant difference overall in the binding-site concentration and the oestradiol level between the two uterine horns in pregnancy. Any influence, therefore, that the blastocyst may have on the uterus, e.g. in opposing the synthesis or the release of luteolysin, is not shown as a marked unilateral change in the oestradiol-binding apparatus of the cell cytoplasm, although oestradiol is known to influence the release of prostaglandin $F_{2 \alpha}$ in the guineapig (Blatchley et al., 1971). The finding that the variability in oestradiol concentration within the uterus of an animal is greater than the binding site variation (Text-fig. 2), however, may have physiological significance.

The high concentration of binding sites in the two ovariectomized cows was in contrast to that found in rats. Feherty et al. (1970) observed a constant low number of sites for at least 28 days after ovariectomy while King et al. (1970) observed a halving of the number of sites/mg DNA after 1 week. Feherty et al. (1970) and Clark \& Gorski (1970), however, found higher numbers of sites/cell in immature than in adult rats, a result which has been confirmed in cattle by Jackson \& Chalkley (1974b) and which is similar to the result obtained in this 
study for the cow whose ovaries appeared inactive. The uteri from this and the two ovariectomized cows were of similar weight (about $15 \%$ of the mean weight for cows during the oestrous cycle), and it seems likely that they all resembled uteri from immature animals. The binding proteins may appear initially, therefore, with only minimal (if any) oestrogen stimulation (Clark \& Gorski, 1970).

The properties of the binding proteins have not been examined in this investigation. More than one type of high affinity receptor may be present as in the immature rat (Michel et al., 1974).

\section{ACKNOWLEDGMENTS}

The financial assistance of the Wellcome Trust is gratefully acknowledged. I thank Dr G. P. Roberts (I.R.A.D.) and Dr E. Linford (M.A.F.F.) for the provision of animal tissues and Mr F. Barnes, Mr B. B. Brown and Dr J. D. Leaver (N.I.R.D.) for the supply and housing of animals. The use of slaughterhouse facilities at I.R.A.D. is greatly appreciated. I am grateful for the technical assistance provided by Miss S. J. Robertson.

\section{REFERENCES}

BLACK, L.J. \& KRAAY, R.J. (1973) Evaluation of two types of oestrogen inhibition with regard to effects on uptake and binding of $\left[{ }^{3} \mathrm{H}\right]$ oestradiol in the uterus. 7. Steroid Biochem. 4, 467-475.

Blatchley, F.R., Donovan, B.T., Poyser, N.L., Horton, E.W., Thompson, C.J. \& Los, M. (1971) Identification of prostaglandin $F_{2 z}$ in the utero-ovarian blood of guinea-pig after treatment with oestrogen. Nature, Lond. 230, 243-244.

BRtNSFIELD, T.H. \& HAWK, H.W. (1974) Ultrastructure of sheep endometrial stromal cells after ovariectomy and hormone treatment. Biol. Reprod. 10, 98-102.

Burton, K. (1956) A study of the conditions and mechanism of the diphenylamine reaction for the colorimetric estimation of deoxyribonucleic acid. Biochem. 7. 62, 315-323.

Chatkoff, M.L. \& Julian, J.A. (1973) Effects of progesterone on the binding of oestradiol-receptor to rabbit uterine chromatin. Biochem. biophys. Res. Commun. 51, 1015-1022.

CLARK, J.H. \& GoRsKI, J. (1970) Ontogeny of the estrogen receptor during early uterine development. Science, N.Y. 169, 76-78.

De Sombre, E.R., Chabaud, J.P., Puga, G.A. \& Jensen, E.V. (1971) Purification and properties of an estrogen-binding protein from calf uterus. F. Steroid Biochem. 2, 95-103.

Dobrowolski, W. \& HAFEz, E.S.E. (1971) The uterus and control of ovarian function. Acta obstet. gynec. scand., Suppl. 12.

Dosson, H. \& Dean, P.D.G. (1974) Radioimmunoassay of oestrone, oestradiol-17 $\alpha$ and oestradiol-17 $\beta$ in bovine plasma during the oestrous cycle and last stages of pregnancy. F. Endocr. 61, 479-486.

EChternkamp, S.E. \& HANSEL, W. (1973) Concurrent changes in bovine plasma hormone levels prior to and during the first post-partum estrous cycle. F. Anim. Sci. 37, 1362-1370.

Evans, L.H., Martin, J.D. \& Hahnel, R. (1974) Estrogen receptor concentration in normal and pathological human uterine tissues. F. clin. Endocr. Metab. 38, 23-32.

Feherty, P., Robertson, D.M., Waynforth, H.B. \& Kellie, A.E. (1970) Changes in the concentration of high-affinity oestradiol receptors in rat uterine supernatant preparations during the oestrous cycle, pseudopregnancy, pregnancy, maturation and after ovariectomy. Biochem. $\mathcal{F}$. $120,837-844$.

Finn, C.A. \& MARTIN, L. (1973) Endocrine control of gland proliferation in the mouse uterus. Biol. Reprod. 8, 585-588.

Gentry, B.E., ANDerson, L.L. \& MrLampy, R.M. (1973) Exogenous progesterone and estradiol benzoate on early embryonic survival in the pig. F. Anim. Sci. 37, 722-727.

Glencross, R.G., Munro, I.B., Senior, B.E. \& Pope, G.S. (1973) Concentrations of oestradiol-17 $\beta$, oestrone and progesterone in jugular venous plasma of cows during the oestrous cycle and in early pregnancy. Acta endocr., Copenh. 73, 374-384. 
Hawk, H.W., Wiltbank, J.N., Kidder, H.E. \& Casida, L.E. (1955) Embryonic mortality between 16 and 34 days post-breeding in cows of low fertility. F. Dairy Sci. 38, 673-676.

Hawk, H.W., Brinsfield, T.H., Turner, G.D., Whitmore, G.E. \& Norcross, M.A. (1963) Embryo survival in first-service and repeat breeder cattle after ovariectomy and hormone therapy. 7. Dairy Sci. 46, 1397-1401.

JaGkson, V. \& GhalkLey, R. (1974a) The cytoplasmic estradiol receptors of bovine uterus. Their occurrence, interconversion, and binding properties. F. biol. Chem. 249, 1627-1636.

Jackson, V. \& ChalkLey, R. (1974b) The binding of estradiol-17 $\beta$ to the bovine endometrial nuclear membrane. F. biol. Chem. 249, 1615-1626.

Jensen, E.V. \& De Sombre, E.R. (1972) Mechanism of action of the female sex hormones. A. Rev. Biochem. 41, 203-230.

Jensen, E.V. \& Jacosson, H.I. (1962) Basic guides to the mechanism of oestrogen action. Recent Prog. Horm. Res. 18, 387-414.

Katzenellenbogen, B.W. \& Gorski, J. (1972) Estrogen action in vitro. Induction of the synthesis of a specific uterine protein. F. biol. Chem. 247, 1299-1305.

Kimball, F.A. \& Hansel, W. (1973) Estrogen binding protein in bovine endometrium and corpus luteum during the estrous cycle. Proc. Am. physiol. Soc. 16, 363.

King, R.J.B., Steggles, A.W., Gordon, J. \& Marx, J. (1970) Role of endogenous hormones in uterine binding of oestradiol-17 $\beta$. Biochem. F. 118, 10P-11P.

LEE, A.E. (1974) Effects of oestrogen antagonists on mitosis and $\left[{ }^{3} \mathrm{H}\right]$ cestradiol binding in the mouse uterus. F. Endocr. 60, 167-174.

LEE, A.E. \& DUKELow, W.R. (1972) Synthesis of DNA and mitosis in rabbit uteri after oestrogen and progesterone injections, and during early pregnancy. F. Reprod. Fert. 31, 473-476.

LEE, C. \& JAGOBSON, H.I. (1971) Uterine estrogen receptor in rats during pubescence and the estrous cycle. Endocrinology 88, 596-601.

MAHLER, H.R. \& Cordes, E.H. (1966) Biological Chemistry, p. 137. Harper \& Row, New York.

MARTin, L. \& FinN, G.A. (1970) Interactions of oestradiol and progestins in the mouse uterus. $\mathcal{F}$. Endocr. 48, 109-115.

Martin, L., Finn, G.A. \& CARTER, J. (1970) Effects of progesterone and oestradiol-17 $\beta$ on the luminal epithelium of the mouse uterus. 7. Reprod. Fert. 21, 461-469.

Martin, L., Das, R.M. \& Finn, C.A. (1973) The inhibition by progesterone of uterine epithelial proliferation in the mouse. F. Endocr. 57, 549-554.

Mester, J., Robertson, D.M., Feherty, P. \& Keline, A.E. (1970) Determination of high affinity oestrogen receptor sites in uterine supernatant preparations. Biochem. F. 120, 831-836.

Michel, G., Jung, I., Baulieu, E-E., Aussed, C. \& URIEL, J. (1974) Two high affinity estrogen binding proteins of different specificity in the immature rat uterus cytosol. Steroids, 24, 437-449.

NalBandov, A.V. (1971) Endocrine control of implantation. In Biology of the Blastocyst, pp. 383-392. Ed. R. J. Blandau. University of Chicago Press, Chicago.

Puca, G.A., Nola, E., Sica, V. \& Bresciani, F. (1971) Estrogen-binding proteins of calf uterus. Partial purification and preliminary characterization of two cytoplasmic proteins. Biochemistry, Easton 10, 3769-3780.

Rowson, L.E.A., LAwson, R.A.S., Moor, R.M. \& BAker, A.A. (1972) Egg transfer in the cow: synchronization requirements. F. Reprod. Fert. 28, 427-431.

SARFF, M. \& GoRskI, J. (1971) Control of estrogen binding protein concentration under basal conditions and after estrogen administration. Biochemistry, Easton 10, 2557-2563.

SCATchard, G. (1949) The attractions of proteins for small molecules and ions. Ann. N.Y. Acad. Sci. $51,660-672$.

Smith, J.A., Martin, L., King, R.J.B. \& Vertes, M. (1970) Effects of oestradiol-17 $\beta$ and progesterone on total and nuclear protein synthesis in epithelial and stromal tissues of the mouse uterus and of progesterone on the ability of these tissues to bind oestradiol-17 $\beta$. Biochem. F. 119, 773-784.

StumpF, W.E. \& SAR, M. (1973) Cellular and subcellular localization of $\left[{ }^{3} \mathrm{H}\right]$ progesterone and its metabolites in rat uterus studied by autoradiography. F. Steroid Biochem. 4, 477-481.

WAgner, R.K., GoRlich, L. \& Jungblut, P.W. (1972) Multiple steroid hormone receptors in calf uterus. Binding specificities and distribution. Hoppe-Seylers Z. physiol. Chem. 353, 1654-1656. 